\title{
HUBUNGAN ANTARA PERILAKU PENGGUNAAN LAPTOP DENGAN KELUHAN KESEHATAN AKIBAT PENGGUNAAN LAPTOP
}

\author{
Yuswati*Mokh Firman Ismana**
}

\begin{abstract}
ABSTRAK
Menguatnya daya beli konsumen berdampak pada penjualan notebook atau laptop. Penggunaan laptop juga menjadi sesuatu yang fenomenal di perguruan tinggi, termasuk dalam lingkungan STIKes Cirebon mulai dari kalangan dosen, karyawan dan terutama mahasiswa. Perilaku penggunaan laptop yang kurang baik dapat menimbulkan keluhan kesehatan pada pengguna. Berdasarkan hasil penelitian didapat bahwa mahasiswa reguler program studi kesehatan masyarakat STIKes Cirebon mayoritas memiliki keluhan disetiap bagian tubuhnya yaitu pada musculoskeletal dan pada mata. Tujuan penelitian ini untuk mengetahui hubungan antara perilaku penggunaan laptop dengan keluhan kesehatan akibat penggunaan laptop pada mahasiswa reguler program studi kesehatan masyarakat STIKes Cirebon Tahun 2015. Metode pengumpulan data dilakukan dengan wawancara menggunakan instrument penelitian berupa kuesioner. Rancangan penelitian menggunakan desain cross sectional, dengan populasi dan sampel seluruh mahasiswa reguler program studi kesehatan masyarakat tingkat IIV STIKes Cirebon Tahun 2015 sebanyak 65 responden. Data dianalisis secara statistik menggunakan uji chi square pada tingkat kemaknaan 5\% (0,05). Hasil penelitian ini menunjukan tidak ada hubungan yang bermakna antara ukuran laptop dengan keluhan kesehatan yang dirasakan akibat penggunaan laptop (Pvalue $=0,961)$, tidak ada hubungan yang bermakna antara durasi penggunaan laptop dengan keluhan kesehatan yang dirasakan akibat penggunaan laptop ( Pvalue $=0,782$ ), tidak ada hubungan yang bermaknaantara frekuensi penggunaan laptop dengan keluhan kesehatan yang dirasakan akibat penggunaan laptop (Pvalue $=0,065$ ), ada hubungan yang bermakna antara antara posisi tubuh saat menggunakan laptop dengan keluhan kesehatan yang dirasakan akibat penggunaan laptop (Pvalue $=0,002)$.
\end{abstract}

Kata Kunci : Ukuran, durasi dan frekuensi penggunaan laptop

\begin{abstract}
The strengthening of consumer purchasing power affects the sales of notebook or laptop. The use of laptops also be something phenomenal in college, including Cirebon STIKes environments ranging from the faculty, staff and especially students. Laptop usage behavior can cause adverse health complaints on the user. Based on the results of the study found that regular students of public health studies program STIKes Cirebon majority of complaints every part of his body is in musculoskeletal and eyes. The purpose of this study was to determine the relationship between the behavior of the use of a laptop with health complaints as a result of the use of laptops in the regular students of public health studies program STIKes Cirebon 2015. Method of data collection is done with the interview using a research instrument in the form of a questionnaire. The study design was crosssectional design, with a sample of the entire student population and the regular program of public health studies I-IV level STIKes Cirebon in 2015 as many as 65 respondents. Data were statistically analyzed using chi square test at 5\% significance level (0.05). Results of this study showed no significant relationship between the size of a laptop with the perceived health complaints as a result of the use of a laptop (pvalue $=0.961$ ), there was no significant association between duration of use of a laptop with the perceived health complaints as a result of the use of a laptop (pvalue $=0.782$ ), not No significant association between the frequency of the use of a laptop with the perceived health complaints due to the use of a laptop (pvalue $=0.065$ ), there was a significant correlation between the position of the body when using a laptop with perceived health complaints due to the use of a laptop (pvalue $=0.002)$.
\end{abstract}

Keywords : Size, duration, frequencythe use of laptops

\footnotetext{
* Staf Pengajar PSKM STIKes Cirebon

** Staf Pengajar PSKM STIKes Cirebon
} 


\section{PENDAHULUAN}

Penggunaan laptop meningkat sangat tinggi di dunia pendidikan, baik di kalangan anak sekolah maupun perguruan tinggi. Mayoritas anak-anak sekolah saat ini selalu membawa laptop ke sekolah karena tuntutan zaman yang semakin canggih. ${ }^{1}$

Penggunaan laptop juga menjadi sesuatu yang fenomenal di perguruan tinggi, termasuk dalam lingkungan STIKes Cirebon mulai dari kalangan dosen, mahasiswa, hingga karyawan. Bagi mahasiswa, laptop yang ditunjang dengan adanya fasilitas hotspot di lingkungan STIKes Cirebon lebih banyak digunakan untuk browsing bahan kuliah maupun berita, mengerjakan tugas, dan menjelajah jejaring sosial untuk memperluas pergaulan. ${ }^{1}$

Kehadiran laptop selain dapat memberikan dampak positif juga dapat memberikan dampak negatif bagi penggunanya. Salah satu dampak negatifnya adalah desain laptop yang cenderung kurang memperhatikan ergonomi bagi penggunanya, seperti keyboard dan monitor. Susunan huruf di keyboard yang menggunakan standar asing membuat laptop di Indonesia harus menyesuaikan lagi dengan susunan hurufnya. Monitor yang menyatu dengan keyboard akan membuat pengguna kesulitan menerapkan sikap dan perilaku ergonomi yang baik. ${ }^{1}$

Menurut teori yang dikemukakan oleh Bloom, bahwa perilaku manusia dapat di bagi kedalam 3 domain (ranah) yaitu ranah kognitif, ranah afektif, dan ranah psikomotor. Ketiga ranah tersebut diukur melalui pengetahuan (knowledge), sikap (attitude), dan praktik (practical). $^{2}$

Pengetahuan adalah hasil penginderaan manusia, atau hasil tahu seseorang terhadap obyek melalui indera yang dimilikinya (mata, hidung, telinga, dan sebagainya). Dengan didasari pengetahuan diharapkan sikap dan perilaku akan mengikuti. ${ }^{2}$

Perilaku dalam penggunaan laptop yang tidak baik seperti monitor yang menyatu dengan keyboard pada laptop mengakibatkan ruang gerak tangan untuk mengetik menjadi sempit, posisi pergelangan tangan tidak ergonomis, dan posisi siku tidak membentuk sudut $90^{\circ}$. Hal ini nantinya akan berdampak buruk bagi kesehatan terutama musculoskeletal. Gangguan pada bagian lengan dan telapak tangan awalnya dirasakan nyeri oleh pengguna laptop pada bagian pergelangan, nyeri siku, hingga cedera yang lebih serius seperti Carpal Tunnel Syndrome, yaitu terjepitnya saraf di bagian pergelangan yang menyebabkan nyeri di seluruh tangan. Cedera ini harus segera diatasi sebelum terlambat, karena pada stadium lanjut harus dilakukan tindakan operasi. ${ }^{3}$

Berdasarkan penelitian terdahulu terkait perilaku dan keluhan kesehatan akibat penggunaan laptop pada mahasiswa sarjana reguler fakultas ilmu komputer universitas indonesia oleh Ananda Puspitasari (2012) dengan sampel yang digunakan sebesar 116 responden didapatkan hasil bahwa perilaku penggunaan laptop yang meliputi ukuran laptop yang digunakan responden dibagi menjadi dua kategori, yaitu ukuran kecil sebanyak $22,4 \%$ dan ukuran besar sebanyak $77,6 \%$. Penggunaan laptop dengan frekuensi rendah sebesar $6 \%$ dan frekuensi tinggi sebesar $94 \%{ }^{4}$

Penggunaan laptop dengan durasi rendah sebesar 0,9\% dan durasi tinggi sebesar 99,1\%. Penggunaan laptop dengan posisi tubuh buruk sebesar 52,60\% dan posisi tubuh baik sebesar $47,40 \%$. Hal ini dapat disebabkan karena beberapa hal, yaitu desain tempat kerja yang kurang ergonomis, durasi dan frekuensi penggunaan laptop yang tinggi, belum menerapkan beberapa prinsip ergonomi dengan baik, dan bentuk laptop yang tidak ergonomis. ${ }^{4}$ Tingkat keparahan dari keluhan kesehatan yang dirasakan responden dibagi menjadi dua kategori, yaitu ringan sebesar 44,8\% dan parah sebesar 55,2\%. ${ }^{4}$

Mahasiswa Reguler Program Studi Kesehatan Masyarakat STIKes Cirebon Tahun 2015 tingkat I-IV termasuk yang berpotensi mengalami gangguan kesehatan akibat penggunaan laptop yang tidak baik karena hampir semua mahasiswa menggunakan bantuan laptop dalam kegiatan perkuliahan. 
Berdasarkan studi pendahuluan pada tanggal 1-2 Juni 2015 terhadap 20 responden mahasiswa reguler program studi kesehatan masyarakat STIKes Cirebon Tahun 2015 tingkat I (satu), didapatkan hasil bahwa perilaku penggunaan laptop yang meliputi ukuran laptop yang digunakan responden dibagi menjadi dua kategori, yaitu ukuran kecil sebanyak $45 \%$ dan ukuran besar sebanyak 55\%. Penggunaan laptop dengan frekuensi rendah sebesar 10\% dan frekuensi tinggi sebesar $90 \%$.

Penggunaan laptop dengan durasi rendah sebesar $40 \%$ dan durasi tinggi sebesar $60 \%$. Penggunaan laptop dengan posisi tubuh buruk sebesar 50\% dan posisi tubuh baik sebesar $50 \%$. Hal ini dapat disebabkan jarak layar dan mata terlalu jauh ketinggiannya sehingga membuat pengguna harus membungkuk. Selain itu, posisi lengan saat menggunakan keyboard tidak membentuk sudut $90^{\circ}$, dan lain-lain. Perilaku penggunaan laptop yang tidak baik ini, akan membuat mereka beresiko terkena gangguan kesehatan akibat penggunaan laptop.

Jenis keluhan yang paling banyak dirasakan adalah pegal dan kesemutan, sedangkan keluhan pada bagian mata sebanyak 32 responden dengan jenis keluhan yang paling banyak dirasakan adalah mata lelah. Tingkat keparahan dari keluhan kesehatan yang dirasakan responden dibagi menjadi dua kategori, yaitu ringan sebesar 50\% dan parah sebesar $50 \%$.

Tujuan penelitian ini untuk mengetahui hubungan antara perilaku penggunaan laptop dengan keluhan kesehatan akibat penggunaan laptop pada mahasiswa reguler program studi kesehatan masyarakat STIKes Cirebon Tahun 2015.

\section{METODE PENELITIAN}

Penelitian ini dilakukan dengan menggunakan pendekatan kuantitatif dengan desain cross sectional. Populasi dalam penelitian ini adalah seluruh mahasiswa reguler program studi kesehatan masyarakat tingkat I-IV STIKes Cirebon Tahun 2015 sebanyak 65 responden. Sampel yang diambil dalam penelitian ini menggunakan metode total sampling. Metode pengumpulan data yang digunakan dalam penelitian ini yaitu dengan menggunakan wawancara Instrumen yang digunakan dalam penelitian ini adalah kuesioner yang mengadopsi dari kuesioner yang telah digunakan sebelumnya oleh Ananda Puspitasari (2012). Analisis data menggunakan analisis univariat dengan distribusi frekuensi dan persentase dari tiap variabel. Analisis yang digunakan untuk mengetahui hubungan antara variabel bebas yaitu perilaku penggunaan laptop (ukuran laptop, durasi penggunaan laptop, frekuensi penggunaan laptop, dan posisi tubuh saat menggunakan laptop) dengan keluhan kesehatan akibat penggunaan laptop.Analisis dilakukan dengan uji statistik uji chi square. Dengan kriteria pengujian hipotesis apabila nilai pvalue $>\alpha(0,05)$ maka hasilnya tidak bermakna secara statistik atau tidak terdapat hubungan yang bermakna (Ho diterima), sedangkan apabila nilai Pvalue $\leq \alpha(0,05)$ maka hasilnya bermakna secara statistik atau terdapat hubungan yang bermakna (Ho ditolak).

\section{HASIL PENELITIAN}

\section{Keluhan Kesehatan}

Hasil penelitian menunjukkan bahwa dari 65 responden yang diteliti, mahasiswa reguler program studi kesehatan masyarakat tingkat I-IV STIKes Cirebon Tahun 2015 merasakan keluhan di setiap bagian tubuhnya (leher, bahu, siku, lengan, pergelangan tangan, jari-jari, punggung atas, punggung bawah, pinggang, kaki, mata). 
Tabel 1. Distribusi Frekuensi Jumlah Keluhan Kesehatan yang dirasakan per bagian tubuh akibat penggunaan laptop

\begin{tabular}{lllllllll}
\hline \multirow{2}{*}{ Bagian Tubuh } & \multicolumn{3}{c}{ 1 Keluhan } & \multicolumn{2}{c}{ 2 Keluhan } & \multicolumn{2}{c}{$\geq 3$ Keluhan } & \multicolumn{2}{c}{ Total } \\
\cline { 2 - 9 } & $\mathrm{n}$ & $\%$ & $\mathrm{n}$ & $\%$ & $\mathrm{n}$ & $\%$ & $\mathrm{~N}$ & $\%$ \\
\hline Leher & 37 & & 17 & 26 & 17 & 26 & 65 & 100 \\
Bahu & 39 & 60 & 13 & 20 & 13 & 20 & 65 & 100 \\
Siku & 41 & 63 & 17 & 26 & 17 & 26 & 65 & 100 \\
Lengan & 38 & 58 & 21 & 32 & 21 & 32 & 65 & 100 \\
Pergelangan tangan & 39 & 60 & 18 & 28 & 18 & 28 & 65 & 100 \\
Jari-jari & 45 & 70 & 10 & 15 & 10 & 15 & 65 & 100 \\
Punggung atas & 37 & 57 & 18 & 28 & 18 & 28 & 65 & 100 \\
Punggung bawah & 42 & 65 & 13 & 20 & 13 & 20 & 65 & 100 \\
Pinggang & 39 & 60 & 16 & 25 & 16 & 25 & 65 & 100 \\
Kaki & 36 & 55 & 22 & 34 & 22 & 34 & 65 & 100 \\
Mata & 27 & 42 & 16 & 25 & 16 & 25 & 65 & 100 \\
\hline
\end{tabular}

Berdasarkan tabel 1 diketahui bahwa dari 65 responden yang diteliti memiliki minimal satu keluhan pada masing-masing bagian tubuh yang diteliti. Keluhan kesehatan pada musculoskeletal (leher, bahu, siku tangan, lengan tangan, pergelangan tangan, jari-jari, punggung atas, punggung bawah, pinggang dan kaki) yang paling banyak dirasakan yaitu dengan jenis keluhan pegal dan pada bagian mata yaitu dengan jenis keluhan mata lelah.

Berdasarkan hasil penelitian keluhan kesehatan akibat penggunaan laptop yang dirasakan mahasiswa berada dalam tingkat parah, dengan jumlah sebesar 57\% atau 37 mahasiswa, sedangkan yang berada dalam tingkat ringan sebesar $43 \%$ atau 28 mahasiswa.

\section{Ukuran Laptop}

Hasil penelitian menunjukkan bahwa dari 65 responden yang diteliti yang menggunakan laptop dengan ukuran besar $\geq 14$ inci, sebesar 64,6\% (42 mahasiswa).

\section{Durasi Penggunaan Laptop}

Hasil penelitian menunjukkan bahwa dari 65 responden yang diteliti yang menggunakan laptop dengan durasi tinggi $>2$ jam, yaitu sebesar 66\% (43 mahasiswa).

\section{Frekuensi Penggunaan Laptop}

Hasil penelitian menunjukkan bahwa dari 65 responden yang diteliti yang menggunakan laptop dengan frekuensi rendah $\leq 5$ hari, yaitu sebesar 58\% (38 mahasiswa).

\section{Posisi Tubuh Saat Menggunakan Laptop}

Hasil penelitian menunjukkan bahwa dari 65 responden yang diteliti yang memiliki posisi tubuh buruk saat menggunakan laptop, yaitu sebesar 50,8\% (33 mahasiswa). 


\section{Hubungan antara perilaku penggunaan laptop dengan keluhan kesehatan akibat penggunaan laptop}

Tabel 2. Hasil analisis bivariat hubungan antara perilaku penggunaan laptop dengan keluhan kesehatan akibat penggunaan laptop

\begin{tabular}{|c|c|c|c|c|c|c|c|}
\hline \multirow{3}{*}{ Variabel } & \multicolumn{6}{|c|}{ Keluhan Kesehatan total } & \multirow{3}{*}{ Pvalue } \\
\hline & \multicolumn{2}{|c|}{ Parah } & \multicolumn{2}{|c|}{ Ringan } & \multicolumn{2}{|c|}{ Total } & \\
\hline & $\mathrm{N}$ & $\%$ & $\mathrm{~N}$ & $\%$ & $\mathrm{~N}$ & $\%$ & \\
\hline \multicolumn{8}{|c|}{$\begin{array}{l}\text { Ukuran laptop yang } \\
\text { Digunakan }\end{array}$} \\
\hline Kecil & 13 & 56,5 & 10 & 43,5 & 23 & 100 & \multirow{2}{*}{1.000} \\
\hline Besar & 28 & 67 & 14 & 33 & 42 & 100 & \\
\hline \multicolumn{8}{|c|}{$\begin{array}{l}\text { Durasi penggunaan } \\
\text { Laptop }\end{array}$} \\
\hline Rendah & 12 & 54,5 & 10 & 45,5 & 22 & 100 & \multirow{2}{*}{0.990} \\
\hline Tinggi & 25 & 58,1 & 18 & 41,9 & 43 & 100 & \\
\hline \multicolumn{8}{|c|}{$\begin{array}{l}\text { Frekuensi penggunaan } \\
\text { Laptop }\end{array}$} \\
\hline Rendah & 18 & 47,3 & 20 & 52,7 & 38 & 100 & \multirow{2}{*}{0.112} \\
\hline Tinggi & 19 & 70,3 & 8 & 29,7 & 27 & 100 & \\
\hline \multicolumn{8}{|c|}{$\begin{array}{l}\text { Posisi tubuh saat } \\
\text { menggunakan laptop }\end{array}$} \\
\hline Baik & 12 & 37,5 & 20 & 62,5 & 32 & 100 & \multirow{2}{*}{0.004} \\
\hline Buruk & 25 & 75,7 & 8 & 24,3 & 33 & 100 & \\
\hline
\end{tabular}

\section{Hubungan antara ukuran laptop dengan keluhan kesehatan yang dirasakan akibat penggunaan laptop.}

Berdasarkan tabel 2 hasil analisis hubungan antara ukuran laptop dengan keluhan kesehatan yang dirasakan akibat penggunaan laptop pada mahasiswa reguler program studi kesehatan masyarakat STIKes Cirebon Tahun 2015diperoleh bahwa dari 23 mahasiswa yang menggunakan laptop ukuran kecil yang mengalami keluhan parah sebesar 56,5\% dan yang mengalami keluhan ringan sebesar 43,5\%. Sedangkan dari 42 mahasiswa yang menggunakan ukuran laptop besar, yang mengalami keluhan parah sebesar $67 \%$ dan yang mengalami keluhan ringan sebesar 33\%.

Berdasarkan hasil uji statistik diperoleh nilai pvalue 1.000 yang berarti nilai $\mathrm{p}>\alpha$ dengan $\alpha=0,05$, hal ini menunjukan tidak ada hubungan yang bermakna antara ukuran laptop dengan keluhan kesehatan yang dirasakan akibat penggunaan laptop.

\section{Hubungan antara durasi penggunaan laptop dengan keluhan kesehatan yang dirasakan akibat penggunaan laptop.}

Berdasarkan tabel 2 hasil analisis hubungan antara durasi penggunaan laptop dengan keluhan kesehatan yang dirasakan akibat penggunaan laptop pada mahasiswa reguler program studi kesehatan masyarakat STIKes Cirebon Tahun 2015 diperoleh bahwa dari 22 mahasiswa yang menggunakan laptop dengan durasi rendah, yang mengalami keluhan parah sebesar $54,5 \%$ dan yang mengalami keluhan ringan sebesar 45,5\%. Sedangkan dari 43 mahasiswa yang menggunakan laptop dengan durasi tinggi, yang mengalami keluhan parah sebesar $58,1 \%$ dan yang mengalami keluhan ringan sebesar $41,9 \%$. 
Berdasarkan hasil uji statistik diperoleh nilai pvalue 0.990 yang berarti nilai $\mathrm{p}>\alpha$ dengan $\alpha=0,05$, hal ini menunjukan tidak ada hubungan yang bermakna antara durasi penggunaan laptop dengan keluhan kesehatan yang dirasakan akibat penggunaan laptop.

\section{Hubungan antara frekuensi penggunaan laptop dengan keluhan kesehatan yang dirasakan akibat penggunaan laptop.}

Berdasarkan tabel 2 hasil analisis hubungan antara frekuensi penggunaan laptop dengan keluhan kesehatan yang dirasakan akibat penggunaan laptop pada mahasiswa reguler program studi kesehatan masyarakat STIKes Cirebon Tahun 2015 diperoleh bahwa dari 38 mahasiswa yang menggunakan laptop dengan durasi rendah, yang mengalami keluhan parah sebesar $47,3 \%$ dan yang mengalami keluhan ringan sebesar 52,7\%. Sedangkan dari 27 mahasiswa yang menggunakan laptop dengan durasi tinggi, yang mengalami keluhan parah sebesar $70,3 \%$ dan yang mengalami keluhan ringan sebesar $29,7 \%$.

Berdasarkan hasil uji statistik diperoleh nilai pvalue 0.112 yang berarti nilai $p>\alpha$ dengan $\alpha=0,05$,hal ini menunjukan tidak ada hubungan yang bermakna antara frekuensi penggunaan laptop dengan keluhan kesehatan yang dirasakan akibat penggunaan laptop.

\section{Hubungan antara posisi tubuh saat menggunakan laptop dengan keluhan kesehatan yang dirasakan akibat penggunaan laptop.}

Berdasarkan tabel 2 hasil analisis hubungan antara posisi tubuh saat menggunakan laptop dengan keluhan kesehatan yang dirasakan akibat penggunaan laptop pada mahasiswa reguler program studi kesehatan masyarakat STIKes Cirebon Tahun 2015 diperoleh bahwa dari 32 mahasiswa yang menggunakan laptop dengan durasi rendah, yang mengalami keluhan parah sebesar $37,5 \%$ dan yang mengalami keluhan ringan sebesar 62,5\%. Sedangkan dari 33 mahasiswa yang menggunakan laptop dengan durasi tinggi, yang mengalami keluhan parah sebesar $75,7 \%$ dan yang mengalami keluhan ringan sebesar $24,3 \%$.

Berdasarkan hasil uji statistik diperoleh nilai pvalue 0.004 yang berarti nilai $\mathrm{p}<\alpha$ dengan $\alpha=0,05$, hal ini menunjukan ada hubungan yang bermakna antara posisi tubuh saat menggunakan laptop dengan keluhan kesehatan yang dirasakan akibat penggunaan laptop.

\section{PEMBAHASAN}

\section{Ukuran Laptop yang Digunakan}

Berdasarkan hasil analisis ukuran laptop yang digunakan oleh mahasiswa reguler program studi kesehatan masyarakat tingkat I-IV STIKes Cirebon Tahun 2015, diperoleh data bahwa mayoritas mahasiswa menggunakan laptop dengan ukuran besar $\geq 14$ inci, sebesar $64,6 \%$. Ukuran laptop $\geq 14$ inci merupakan ukuran standar karena telah memenuhi syarat ergonomi laptop. ${ }^{5}$

Berdasarkan hasil wawancara singkat kepada beberapa responden, bahwa alasan mereka memilih menggunakan laptop ukuran $\geq 14$ inci dikarenakan mereka membutuhkan layar, kapasitas processor dan memori yang lebih besar sehingga dapat mendukung semua aplikasi dan software yang diinginkan dalam mengerjakan pekerjaan atau tugas. Dalam ergonomic for laptop user dikatakan bahwa ukuran laptop 14 atau 15 inci merupakan ukuran ideal dan dapat bekerja lebih baik untuk mendukung semua aplikasi. ${ }^{5}$

Berdasarkan hasil uji statistik diperoleh nilai pvalue 1.000 yang berarti nilai $\mathrm{p}>\alpha$ dengan $\alpha=0,05$, hal ini menunjukan tidak ada hubungan yang bermakna antara ukuran laptop dengan keluhan kesehatan yang dirasakan akibat penggunaan laptop.

Hasil penelitian ini sejalan dengan penelitian yang dilakukan oleh Ananda Puspitasari (2012) bahwa tidak ada hubungan yang bermakna antara ukuran laptop dengan keluhan kesehatan yang dirasakan akibat penggunaan laptop ukuran $<14$ atau $\geq 14$ inci. $^{4}$ 
Penelitian ini bertolak belakang dengan penelitian yang dilakukan oleh Oktaviani (2007) yang menyatakan bahwa ada hubungan yang bermakna antara ukuran laptop dengan keluhan kesehatan yang dirasakan akibat penggunaan laptop. ${ }^{6}$ Perbedaan hasil penelitian ini dikarenakan responden penelitian oleh Oktaviani mayoritas menggunakan ukuran laptop kecil dan mengindikasikan bahwa dari kecilnya ukuran layar laptop dan tingkat kejelasan layar menyebabkan rasa tidak nyaman pada mata dan kepala. ${ }^{6}$

\section{Durasi Penggunaan Laptop}

Berdasarkan hasil analisis durasi penggunaan laptop pada mahasiswa reguler program studi kesehatan masyarakat tingkat I-IV STIKes Cirebon Tahun 2015, diperoleh data bahwa mayoritas mahasiswa menggunakan laptop dengan durasi tinggi $>2$ jam, yaitu sebesar $66 \%$.

Berdasarkan hasil wawancara singkat kepada beberapa responden, bahwa alasan mereka menggunakan laptop dengan durasi $>2$ jam (sekali pakai) yaitu karena tuntutan tugas yang mengharuskan mereka menggunakan laptop selama berjam-jam. Selain itu juga digunakan untuk bermain games, yang merupakan aktifitas selingan untuk menghilangkan kejenuhan selama mengerjakan tugas.

Durasi maksimal penggunaan laptop (sekali pakai) adalah 2 jam, apabila terpaksa harus menggunakan laptop dengan durasi yang lebih lama lagi, sebaiknya menggunaan keyboard dan mouse eksternal untuk mengurangi ketidaknyamanan pada musculoskeletal. ${ }^{5}$

Berdasarkan hasil uji statistik diperoleh nilai pvalue 0,990 yang berarti nilai $\mathrm{p}>\alpha$ dengan $\alpha=0,05$, hal ini menunjukan tidak ada hubungan yang bermakna antara durasi penggunaan laptop dengan keluhan kesehatan yang dirasakan akibat penggunaan laptop. Tidak ada perbedaan durasi penggunaan $>2$ jam atau $\leq 2$ jam untuk mengalami keluhan kesehatan yang berat. Hasil penelitian ini sejalan dengan penelitian yang dilakukan oleh Rohmat (2007) pada dosen saat menggunakan laptop dan juga sejalan dengan penelitian oleh Oktaviani (2007) pada mahasiswa UI saat menggunakan laptop, yang keduanya menyatakan bahwa tidak ada hubungan antara durasi penggunaan laptop dengan keluhan kesehatan yang dirasakan akibat penggunaan laptop.

\section{Frekuensi Penggunaan Laptop}

Berdasarkan hasil analisis frekuensi penggunaan laptop pada mahasiswa, diperoleh data bahwa mayoritas mahasiswa menggunakan laptop dengan frekuensi rendah $\leq 5$ hari, yaitu sebesar $83 \%$ atau 54 mahasiswa. Berdasarkan hasil wawancara singkat kepada beberapa responden, bahwa alasan mereka menggunakan laptop dengan frekuensi $\leq 5$ hari yaitu karena tuntutan tugas.

Berdasarkan hasil uji statistik diperoleh nilai $\mathrm{P}$ value 0,112 yang berarti nilai $\mathrm{p}>\alpha$ dengan $\alpha=0,05$, hal ini menunjukan tidak ada hubungan yang bermakna antara frekuensi penggunaan laptop dengan keluhan kesehatan yang dirasakan akibat penggunaan laptop.

Hal ini sejalan dengan penelitian sebelumnya oleh rohmat (2007) dan Oktaviani (2007) yang keduanya menyatakan bahwa tidak ada hubungan antara frekuensi penggunaan laptop dengan keluhan kesehatan yang dirasakan akibat penggunaan laptop.

Menurut analisa penulis, bahwa penggunaan laptop dengan frekuensi rendah atau tinggi tetap dapat menimbulkan keluhan, hal ini dikarenakan posisi penggunaan laptop yang kurang ergonomis, terlebih lagi jika responden tidak melakukan peregangan tubuh saat bekerja atau tidak menyelingi dengan istirahat.

\section{Posisi Tubuh Saat Menggunakan Laptop}

Berdasarkan hasil analisis posisi tubuh saat menggunakan laptop padamahasiswa reguler program studi kesehatan masyarakat tingkat I-IV STIKes Cirebon Tahun 2015, 
diperoleh data bahwa mayoritas mahasiswa memiliki posisi tubuh buruk saat menggunakan laptop, yaitu sebesar 50,8\%.

Berdasarkan hasil uji statistik diperoleh nilai $\mathrm{P}$ value 0.004 yang berarti nilai $\mathrm{p}>\alpha$ dengan $\alpha=0,05$, hal ini menunjukan ada hubungan yang bermakna antara posisi tubuh saat menggunakan laptop dengan keluhan kesehatan yang dirasakan akibat penggunaan laptop. Hal ini sejalan dengan penelitian oleh Straker (2000) yang menyatakan bahwa biasanya keluhan pengguna laptop diakibatkan oleh postur janggal. Namun tidak sejalan dengan penelitian oleh Rohmat (2007) dan Oktaviani (2007) yang menyatakan bahwa tidak ada hubungan yang bermakna antara posisi tubuh saat menggunakan laptop dengan keluhan kesehatan yang dirasakan akibat penggunaan laptop.

Menurut analisa penulis, pengguna laptop dengan posisi baik maupun buruk sama saja tetap mempunyai kemungkinan untuk mengalami keluhan. Keluhan ini bisa saja terjadi bukan hanya akibat perilaku penggunaan laptop, namun bisa terjadi akibat dari berbagai faktor. Diantaranya kondisi desain tempat kerja yang kurang ergonomis, lingkungan yang tidak nyaman, dan kesehatan masing-masing pengguna.

\section{SIMPULAN}

1. Responden lebih banyak mengalami keluhan pada musculoskeletal (leher, bahu, siku tangan, lengan tangan, pergelangan tangan, jari-jari, punggung atas, punggung bawah, pinggang dan kaki) dengan yang paling banyak dirasakan yaitu dengan jenis keluhan pegal dan keluhan pada bagian mata yaitu dengan jenis keluhan mata lelah. Tingkat keparahan pada keluhan yang dirasakan dibagi menjadi dua kategori yaitu tingkat parah dengan jumlah sebesar $57 \%$ dan tingkat ringan sebesar $43 \%$.

2. Responden lebih banyak yang menggunakan laptop dengan ukuran laptop besar $\geq 14$ inci sebesar 64,6\%, responden yang menggunakan laptop dengan durasi tinggi $>2$ jam yaitu sebesar $66 \%$, responden yang menggunakan laptop dengan frekuensi rendah $\leq 5$ hari yaitu sebesar $83 \%$, responden yang menggunakan laptop dengan posisi tubuh buruk saat menggunakan laptop, yaitu sebesar 50,8\%.

3. Tidak ada hubungan antara ukuran laptop dengan keluhan kesehatan yang dirasakan akibat penggunaan laptop pada mahasiswa reguler program studi kesehatan masyarakat STIKes Cirebon Tahun 2015.

4. Tidak ada hubungan antara durasi penggunaan laptop dengan keluhan kesehatan yang dirasakan akibat penggunaan laptop pada mahasiswa reguler program studi kesehatan masyarakat STIKes Cirebon Tahun 2015.

5. Tidak ada hubungan antara frekuensi penggunaan laptop dengan keluhan kesehatan yang dirasakan akibat penggunaan laptop pada mahasiswa reguler program studi kesehatan masyarakat STIKes Cirebon Tahun 2015.

6. Ada hubungan antara posisi tubuh saat menggunakan laptop dengan keluhan kesehatan yang dirasakan akibat penggunaan laptop pada mahasiswa reguler program studi kesehatan masyarakat STIKes Cirebon Tahun 2015

\section{SARAN}

1. Untuk Peneliti Selanjutnya

1) Sebaiknya menambah variabel penelitian, seperti memperhatikan aspek lingkungan, suhu, beban kerja, desain tempat kerja, dan riwayat penyakit sebelumnya.

2) Diharapkan untuk peneliti selanjutnya apabila akan melakukan penelitian serupa, sebaiknya menggunakan desain penelitian yang lain seperti case control atau kohort yang hasilnya bisa dijadikan penguat atau pembanding terhadap hasil penelitianpenelitian sebelumnya, karena untuk desain case control ada populasi pembandingnya 
sedangkan kohort menggunakan rentang waktu yang lama untuk mengamati perubahan pada obyek sasaran sehingga hasilnya akan lebih akurat, tetapi desain tersebut membutuhkan dana yang lebih tinggi dan waktu yang lebih lama.

3) Jumlah responden yang diteliti lebih banyak jumlahnya namun tetap dalam kriteria jika menggunakan jenis penelitian yang sama.

2. Untuk STIKes Cirebon

1) Perlu memberikan edukasi mengenai posisi penggunaan laptop yang benar serta dampaknya pada mahasiswa, melalui seminar, leaflet, dan poster yang diletakkan pada tempat yang sering dikunjungi mahasiswa saat berada dikampus.

2) Perlu dipertimbangkan untuk menyediakan tempat yang ergonomis untuk mahasiswa yang menggunakan laptop.

3. Untuk seluruh mahasiswa STIKes Cirebon, khususnya mahasiswa reguler program studi kesehatan masyarakat.

1) Selalu memposisikan posisi tubuh yang baik saat menggunakan laptop.

2) Lakukanlah peregangan tubuh disela waktu penggunaan laptop selama 15 menit dan mengalihkan pandangan selama beberapa detik agar mata bisa beristirahat.

3) Gunakanlah keyboard dan mouse eksternal, apabila harus menggunakan laptop cukup lama $>2$ jam.

\section{DAFTAR PUSTAKA}

1. Admin. Prospek penjualan laptop; (diakses tanggal 26 April 2015): Diunduh dari : http://tekno.kompas.com/read/2010/07/30/133842/Prospek.Pasar.Laptop.Semakin.Top

2. Notoatmodjo, S. Promosi Kesehatan dan Ilmu Perilaku. Jakarta: Rineka Cipta; 2007

3. Khaled, T. Analisis risiko ergonomi dan keluhan musculoskeletal pada upper limb extremities akibat penggunaan laptop pada mahasiswa S1 FKM UI. Skripsi. Depok: Fakultas Kesehatan Masyarakat Universitas Indonesia; 2009

4. Puspitasari, A. Hubungan Antara Perilaku Penggunaan Laptop dan Keluhan Kesehatan Akibat Penggunaan Laptop Pada Mahasiswa Sarjana Reguler Fakultas Ilmu Komputer Universitas Indonesia. Skripsi. Depok: Fakultas Kesehatan Masyarakat Universitas Indonesia; 2012

5. Saito, S., Bruno, P., Michael, J., et al. Ergonomics guidelines for using notebook personal computers. Industrial Health, 38

6. Hendra dan Oktaviani D. F. Keluhan kesehatan akibat penggunaan laptop pada mahasiswa FKM UI. Skripsi. Depok: Fakultas Ilmu Kesehatan Masyarakat; 2007 